\title{
The Impacts of Wars on Earnest Hemingway's Works
}

\author{
Jing $\mathrm{Li}^{1}$ \\ ${ }^{1}$ Department of Foreign Languages, Inner Mongolia University for Nationalities, Tongliao, China \\ Correspondence: Jing Li, Department of Foreign Languages, Inner Mongolia University for Nationalities, \\ Tongliao, China. E-mail: lijingeva@163.com
}

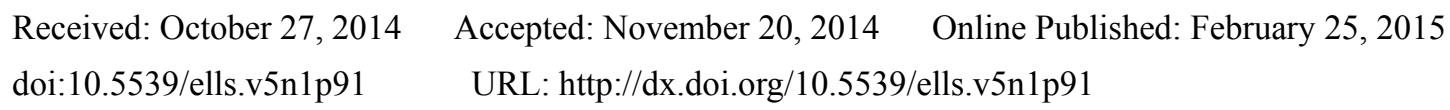

\begin{abstract}
Ernest Hemingway lived in a time full of violence, pain, blood and hostility. He's well known both for his great works and for his adventures. He was the participant of World Wars I and II, and the Spanish Civil War; victim with hundreds of wounds from these wars; the author of great works and many short stories, and also the spokesman for "The Lost Generation". Throughout Hemingway's life, the experiences from various wars and adventures enabled him to witness the bloody battles, violence, life and death of people and provided him with rich sources of writing. Virtually his works and his experiences are inseparable and have been intertwined in many aspects. Looking back through his major works, there is no exception that Hemingway poured his war experiences into his literature works. However, his viewpoints on war were not stable but underwent an ever-changing process.This thesis puts Hemingway into his certain historical time and analyzes the relationship between his protagonists, especially those in his war fictions, and himself. The thesis is also meant to illustrate better how his viewpoints on war are formed and reflected in his fictions.
\end{abstract}

Keywords: Hemingway, anti-war, humanism, death-theme

\section{Introduction}

Ernest Hemingway (1898-1961), is a most famous writer who has contributed greatly to the history of American literature or even world literature. He left the world with a series of vivid characters and a fresh wind of conciseness. Through a series of prominent novels like The Sun Also Rises, A Farewell to Arms, For Whom the Bell Tolls, and The Old Man and the Sea, we can sense his profound thoughts against war and humanism. The suffering of his protagonists is just what Hemingway has suffered, such as the wounds from the wars, the insomnia, and strong frustrations.

\section{Hemingway's War Experiences Reflected in His Fictions}

Hemingway himself suffered a lot from the wars, both physically and psychologically. All the pains helped the formation of his viewpoints about the war-the senses of death and humanism. Surely he poured these senses into his fictions. From his works we see like Hemingway himself, the protagonists usually suffered both physical and psychological pains. They always lived in a violent world, wounded in the war and endured psychological ravages, such as insomnia, and frustration.

On the other hand, the protagonists performed as heroes. What they said and did in the novel manifested their viewpoints about ignoring death and humanism. Those points of view were just what Hemingway held throughout all his life.

\subsection{Hemingway's Physical Pain Reflected in His Fictions}

In A Farewell to Arms, Hemingway obviously draws on his experience to create Frederic Henry's fictional wounding. His suffering enabled him to describe Henry's amply. Actually in Hemingway's fictions, although the names change from novel to novel, the protagonists remained basically the same person. They are often wounded: Henry in A Farewell to Arms, Jake Bernes in The Sun Also Rises, and Nick Adams in the stories of In Our Time, although they got wounded in different ways. Meanwhile, they invariably live in a violent world: Henry in the First World War, Bernes in the ritual violence of the bull-ring, and Robert Jordan (For Whom the Bell Tolls) in the Spanish Civil War. Hemingway was deeply impressed by his injuries and the violence he experienced during the wars, but he, like his protagonists, presents consistently brave faces in public. 


\subsection{Hemingway's Psychological Pain Reflected in His Fictions}

Beyond his physical wounds, Hemingway endured endless psychological pain resulted from the war and he surely transformed these into his arts. Hemingway suffered severe insomnia after the First World War. For a long time he had to keep the light on so that he could sleep. He couldn't walk out from the shadow of the prolonged horror from the war. Like Hemingway, perhaps, Jake in The Sun Also Rises never recovers emotionally from his wound. He needs a light to sleep by in order to get through the night.

After the First World War, Hemingway also got a strong feeling of frustration. But no one, including his parents who still had a romantic notion of war, could understand the psychological impact the war had produced on him. The Sun Also Rises just reflects his maze about life, and reflects the life of those war participants, drinking, dancing, and chasing girls all day long in order to convey their frustration. To them, life is futile. They only replaced the traditional values with their hedonism. When the book was published, numerous young people, those who were called "the Lost Generation" later, recognized themselves in the book, even if they had never been to Paris or seen a bullfight. In fact, such frustration was also reflected in his short story Soldier's Home.

\subsection{Death Theme Reflected in His Fictions}

Hemingway, who covered many wars, surely brushed with death many times. He was even obsessed with the shadow of death though he escaped it time and again. Among all forms of arts, the ancient Greek tragedy seems to be the art, which can bring the greatest enjoyment to human beings. Hemingway profoundly gets the point. He is good at paying attention to and describing the death, and he had a strongly special sense of death. In fact, Hemingway's life and works are closely tied with death.

Hemingway's works, especially his short stories, are filled with killing, blood and death. Hemingway holds the point of view that death is unavoidable and is the biggest and most frightening reality. It has a kind of huge and mysterious power that can deprive people of their lives, rights and everything in a moment. Death is a kind of eternity while love, friendship, and life are nothing but rubbish. Therefore, men shouldn't be intoxicated with the dream of success; happiness and consummation, for death would rob them of their lives at any time. So Hemingway tells of this feeling through a variety of literary figures.

In Indian Camp, Hemingway attaches great importance to the effect of the shocking events on the little boy, Nick, who witnessed them. For the moment, the events do not seem to have any great effect on the naïve boy, but it is very important that Nick turns into a badly scarred and nervous young man. He has experienced the process of thinking about reality and death. In this short story, Nick always witnesses blood, misery, misfortune and death. So he asked, “'why did he kill himself, Daddy?' 'Do many men kill themselves, Daddy?'” (Chen, ed. 1989, p. 69)

In the Killers, Nick experiences another form of death. He is shocked and puzzled by Anderson's silence and refusal to escape from the killers. "I'm going to get out of this town," Nick said, "I can't stand to think about him waiting in the room and knowing he's going to get it. It's too damned awful." (Chen, ed. 1989, p. 222) What Nick feels unable to bear is not merely the terror, but also Anderson's aloof and indifferent responses, which tells him that there is no way out once one is involved in trouble. Unfortunately, the world is full of troubles.

In A Farewell to Arms, Hemingway expressed his interpretation of death through Henry. "The world breaks everyone, and afterwards many are strong at the broken places. But those that it will not break it kill. It kills the very good and the very gentle and the very brave impartially. If you are none of those you can be sure that it will kill you too, but there will be no special hurry." (Hemingway, 1992, p. 73)

Judging by Hemingway's lifetime and works, his sense of death took shape in the 1920s, and the theme of death permeates his works. In view of this, the world is a big battlefield, bullfighting field, and boxing field, which is full of battles and struggle, blood and fire, cruelty and evil, sadness and death, while life is vulnerable, insignificant and filled with defeat and sadness. However, these above-mentioned points of view are not comprehensive in understanding his sense of death. Hemingway's uniqueness lies in the process of changing his mind from horror to calm, until detachment. In his opinion, it is pleasing and comfortable to feel the horror of death and later to achieve detachment of death.

Everyone is doomed to death. It is an eternal and helpless natural law. Hemingway always makes attempts to put death aside and temporarily ignores the grief and agitation in the face of death, which enables him to achieve a kind of moral or spiritual victory. As a result, Hemingway's sense of death includes not only the detailed and vivid description of death and horror, but also an aesthetic activity deprived from struggle and spiritual victory. In the First World War, he carried an unconscious soldier on his back to the aid station in spite of his own serious injuries. Once on the way to the west of Africa, his wife's blood vessel was split. He sent her to the hospital only 
to find that the doctor had gone out fishing. At this time his wife's pulse was weaker and weaker. The intern advised Hemingway to say the last Good-bye to his wife but he refused. Hemingway decided to operate himself. Under the help of the intern, he found the broken blood vessel and cleaned it, then conducted the blood transfusion to his wife. At last his wife was brought around.

In The Short Happy Life of Francis Macomb, the protagonist enjoyed happiness. Short as it was, but indeed it did exist. "You know I don't think I'd ever be afraid of anything again." (Chen, ed. 1989, p. 25) Francis has become a strong man. He dies without regrets. In Hemingway's mind, men should take a positive attitude in the face of death instead of a negative one. No one can escape from death, but his spirit can be detached.

\section{Hemingway's Changing Viewpoints on Wars}

\subsection{Condemnation of the First World War}

Hemingway's fictions are full of his experiences of wounding, especially the one he suffered from the First World War. When the First World War was raging in Europe, Hemingway tried to enlist in the army, but was deferred because of poor vision. He made it to the war as an ambulance driver for the Red Cross, but reluctantly had to end his first war experiences because of a serious wound in his knee. He received fragments from an Austrian mortar shell a few weeks after his arriving. Nevertheless, he still carried an unconscious man on his back a long distance to the aid station under the heavy mortar fire. "He never remembered afterwards how he had covered the final hundred yards. But he made it, delivered his man, and lost consciousness." (Baker, 1969, p. 45) He stayed in hospital for months and had 237 pieces of shell fragments removed from his knee.

When Hemingway returned home from Italy, he found his life rather dull compared to his adventures of war.Again he left home and went back to Europe as a foreign correspondent, for the Toronto Star.

We can see at the beginning, Hemingway had an illusion of war like other youngsters under the demagogic slogan of the USA to "save the world's democracy". But the longer he stayed in the battlefield, the better he knew about war after witnessing the unprecedented massacre of mankind. The so-called heroes of the country, fighting for democracy and glorious sacrifice are full of deception. Hemingway gave detailed descriptions of horror in A Farewell to Arms from his own experiences of the First World War, which could arouse disgust and hatred for the war. In the story, he thinks the war was nothing but a "slaughter house".

In fact, the war not only caused millions of deaths but also disturbed the daily routine of society and produced harmful effects on the living and the survivals. In this novel, Hemingway also described a moving love between Henry, the hero, and Catharine. But the love came to a tragic end with the death of Catharine, which seemed to show that in this disastrous war time, no fruitful life was possible.

The disastrous effects of war on war victims were also presented in Hemingway's short fictions. The unnamed officer in Now I Lay Me and Nick in A Way You'll Never Be suffered psychological trouble caused by wounds. The war destroyed the hope and future of the soldiers, who were badly disabled and crippled in the war, as can be seen in the fiction In Another Country. The retired soldier, Krebs, in Soldier's Home lost natural desires and ambitions and developed strong world weariness. Big Two-Hearted River was a war story without mention of war. Through the fishing trip, Nick, a veteran, was trying to get temporary tranquility of his mind by forgetting about the war and earthly troubles.

Another prominent fiction concerning the First World War by Hemingway was The Sun Also Rises in which the author revealed the war's far-researching and disheartening effects. On the surface level, the novel was just concerned with drinking, eating, fishing, bull-fighting and some love affairs, but the story was still a war story without war. The pain of love between Brett and Jake, lingering throughout the novel was a curse of the war.

Jake was rendered impotent by the war, which deprived him of any possibility to live a normal and happy life; Brett was also the indirect victim of the war. The love between Brett and Jake made a full circle from nothing to nothing. The fishing trip in the novel was not a celebration of natural beauty or a show of a carefree life, but only a temporary escape. Wine was also a pain-killer Jake often resorted to. In the bull-fighting, Jake seemed to learn the code: to behave with dignity by controlling and disciplining his suffering with impotence. His despair and agony were all intended to give a deep insight into the postwar situation. These soldiers had nothing left but unhealed wounds on their body and in their heart.

From 1924 when Hemingway published In Our Time to 1929 when A Farewell to Arms came out, humanism was chiefly revealed in his repeated efforts to show the disaster the First World War brought to mankind and civilization. During this period, the world described in his fictions was one in which things were not growing or bearing fruits but one that was exploding, breaking, decomposing or being eaten away. People could only survive themselves from total misery by visions of endurance, competence and courage or by interludes of love that 
cannot outlast the furlough.

\subsection{Anti-fascism in Spanish Civil War}

When the Spanish Civil War broke out in 1936, Hemingway went to Spain as a correspondent for the North American Newspaper Alliance. He supported the communist loyalists who in turn supported the democratically elected government. Eventually the loyalist movement failed and the Franco led rebels won the war and installed a dictatorial government in the spring of 1939. During the Spanish Civil War, Hemingway sent reports directly from the front to let the world know what was going on. From his humanist point of view, he condemned the fascists for their inhumane crimes: bombing worker's quarters; slaughtering the crowds concentrating in the square; and brutal slaughter of the common people. "...we saw the Fascist artillery doing murder in Madrid and you never see it without hatred and anger."(Brucolli, 1970, p. 235)

From 1936 to 1939, he never stopped his work for the Republic in and out of Spain and he even fought side by side with the Loyalists in the Mountain area south of Madrid. His experience resulted in the famous novel For Whom the Bell Tolls. The story concentrates on Robert Jordan's three days' mission to blow up a bridge behind Fascist lines, in order to cut off the enemy's reinforcing units when the Republican's general attack begins. With the help of Anselmo, a trustworthy old guerrilla, Jordan gets in touch with the guerrilla leader Pablo, who has now turned into a selfish coward and refuses to help, for the action might endanger their camp. Pilar, Pablo's wife agrees to help in the action and gets support from a neighboring guerrilla force. At last the bridge is blown up, but Jordan is wounded seriously in the leg. In this novel, Hemingway expressed the theme of brotherhood and human solidarity, for the involvement of all men in a common humanity. Even the Fascists as well as the Republicans were viewed as equal part of mankind and their deaths were considered a loss to mankind. Thus it seems that Hemingway tries to express his opposition against killing, which is an important theme in the novel.

Although the main characters of the novel such as Jordan, Pilar, and Anselmo were all antifascists, they tended to treat the Fascists as ordinary human beings instead of enemies and express their revolt against killing. Jordan warned himself against killing unless it was necessary. He recalled the two Fascist prisoners shot by him with disgust; and decided never to kill the unarmed. He seemed to be torn between his duty to fight against Fascists and his human principle of valuing human life.

Anselmo, another important figure in the novel, was against all killing of mankind. He believed in reform and education of the enemies rather than killing them. According to Anselmo or Hemingway, to kill can not really terminate enemies but only draw mere hatred and produce more enemies. Like Jordan, Anselmo regarded the Fascists as ordinary human beings instead of enemies. He believed that if he came to the Fascist soldiers, he would be welcomed except that they had orders to challenge all travelers, which he thought, was the only thing that came between them.

In the Spanish Civil War, from the conflicts between freedom and tyranny, democracy and dictatorship, Hemingway discerned a new purpose and meaning of life, which he had been seeking for a long time. Hemingway, as well as Jordan fought relentlessly against Fascism, the evil source of the war and enemy of humanism, and they were willing to die for the cause they believed in. But Hemingway's commitment was a matter of broader humanitarian concern. In For Whom the Bell Tolls, there seemed nothing black and white about Fascists and Loyalists. Although Hemingway stood firmly on the side of the Republic, he accused the Loyalists of their killing of the Fascists for their barbaric atrocity; The antifascists heroes were torn between the necessity to kill the enemy to prevent something worse happening to others and the sense of guilty conscience for their killing of human beings. "All mankind is one volume; Any man's death diminishes me because I am involved in mankind, and therefore never send to know for whom the bell tolls; It tolls for thee."

Hemingway's political stance in the Spanish Civil War was questioned due to his vague and contradictory attitude embodied in the novel. In fact, Hemingway's attitude revealed in the novel resulted from his humanist stance. On one hand, he denounced the crimes committed by Fascists and saw the necessity to kill the Fascists to win the war; on the other hand, he considered killing as a sin, since Fascists were also human beings. From his humanist point of view he criticized both sides for their killing of each other, although his political stance was on the Republican side.

Hemingway's objection of killing led him to the criticism of both sides - the Loyalists and Fascists. His tendency to view Fascists not as enemies revealed his opinion that the Loyalists were not all good and the Fascists were not all bad.

\subsection{Pacifism after the Second World War}

After his work covering the Spanish Civil War and the subsequent work on his novel For Whom the Bell Tolls, 
Hemingway took on another assignment, covering the Chinese-Japanese War in 1941 for PM Magazine. That's his beginning of concern for the Second World War. In the spring of 1944, Hemingway decided to go to Europe to report the European battle field. He went to England at first, and then to France after the allied invasion at Normandy and the liberation of Paris. Next, Hemingway spent a month in the north of France and witnessed the bloodiest of the war-American forces crossing over into Germany. Along with the end of the Second World War, Hemingway also ended his history of experiencing the war himself.

In the 1950s, Hemingway became a pacifist and expressed his disgust with all kinds of wars for their overwhelming disregard of human life, as can be seen in Across the River and into the Trees. It tells a bitter-sweet story of Richard Cantwell, a former brigadier general who was demoted to colonel after a disastrous battle which had been blamed on him. The aging Cantwell, with his heart problem that threatened to kill him at any moment, fell in love with the young Italian countess Renata. They carried out a love affair and through their conversations and monologues we learn the source of Cantwell's bitterness; an inept military that fails to appreciate his talents and in fact sends him orders that are impossible to fulfill, in effect guaranteeing his failure and disgrace. Furthermore, his ex-wife used her relationship with Cantwell to gain access to the military brass for information just for the sake of her journalism career, and a general distaste for the modern world. In this story, Colonel Cantwell was even more sympathetic toward the enemy. In his mind the Fascists and his lost soldiers were the same - the victims of an inhumane war. He even admitted that he loved his enemies.

After the war, Hemingway and his wife Mary, his fourth wife, purchased a home near Havana Cuba. But in his last years, his health deteriorated rapidly and he was also disturbed by severe psychological disease. A lifetime of dangerous physical adventure had taken its toll in numerous injuries, including several severe concussions. In addition, he was suffering from hypertension, mild diabetes and depression, for which he was given electric shock treatments. He became confused, suspicious, and aggressively suicidal; he agonized that he could not write. On July 2, 1961, he selected a shotgun to commit suicide.

\section{Conclusion}

Ernest Hemingway is no doubt among the best short story writers in American literature.The people of that world seemed destined to defeat. However, Hemingway, as a witness of the time, took a positive attitude in the face of death and stood firmly on the side of justice. Meanwhile, he took his experiences as references to craft his works, and poured his points of view - the sense of death and humanism, which formed generally from his personal life experiences and war experiences into it.According to this thesis, we know better how these factors influenced and inspired his writing. We also conclude that only by considering the integration of these two, can we fully understand Hemingway and his works. The author illustrates the relationship between his works and his war experiences from different aspects and analyzes Hemingway's changing thoughts by examples from his works. The humanism Hemingway holds manifests his disgusting, hateful attitudes during the war time. At last he even became a pacifist by experiencing too many killings and deaths. The heroes under his pen are his incarnation of himself and the embodies of his viewpoints towards the society and the world.

\section{Acknowledgments}

I would like to express my gratitude to all those who helped me during the writing of this thesis. My sincere appreciation should go to my colleague Pearl Marguerite from whom I benefited greatly. She has walked me through all the stages of the writing of this thesis. Without her consistent and illuminating instruction, this thesis would be impossible. I am also greatly indebted to all my teachers who have helped me to develop the fundamental and essential academic competence.

\section{References}

Baker, C. (1969). Ernest Hemingway: A Life Story. New York: Scriber's.

Baker, C. (1972). Ernest Hemingway: The Writer as artist. Princeton: Princeton University Press.

Brucolli, M. (Ed.). (1970). Ernest Hemingway: Cub Reporter. University of Pittsburgh Press.

Chen, L. T. (Ed.). (1989). Hemingway Short Stories. Beijing: World Book Publishing House.

Donaldson, S. (2000). The Cambridge Companion to Earnest Hemingway. Shanghai: Shanghai Foreign Language Education Press.

Dong, H. X. (1989). A Critical Biography of Hemingway. Beijing: China Social Sciences Publishing House.

Halsey, W. D. (Ed.). (1985). Collier's Encyclopedia 12. New York: New York Macmillan Education Company.

Hemingway, E. (1926). The Sun Also Rises. New York: New York Charles Scribner's Sons Press. 
Hemingway, E. (1940). For Whom the Bell Tolls. New York: New York Charles Scribner's Sons Press.

Hemingway, E. (1992). A Farewell to Arms. Beijing: Beijing Foreign Language Teaching and Researching Press. Martine, J. J. (Ed.). (1974). American Novelist. New York: New York Charles Scribner's Sons Press.

Unger, L. (Ed.). (1981). American Writers II. Detroit: Detroit Gale Research Company. Book Tower.

Wagner-Martin, L. (2000). A Historical Guide to Earnest Hemingway. London and New York: Oxford University Press.

Wu, R. (1986). Review on Hemingway. Xi'an: Shanxi People's Press.

Zhai, S. Z. (Ed.). (1997). Selected Readings of American Literature. Zhengzhou: Henan University Press.

\section{Copyrights}

Copyright for this article is retained by the author(s), with first publication rights granted to the journal.

This is an open-access article distributed under the terms and conditions of the Creative Commons Attribution license (http://creativecommons.org/licenses/by/3.0/). 